\title{
DiscoverArchive
}

Retrieved from DiscoverArchive,

Vanderbilt University’s Institutional Repository

This work was originally published as Suzanna Sherry, Hogs Get Slaughtered at the Supreme Court, in Supreme Court Review 12011. 
Hogs Get Slaughtered at the Supreme Court

Author(s): Suzanna Sherry

Reviewed work(s):

Source: The Supreme Court Review, Vol. 2011, No. 1 (2011), pp. 1-37

Published by: The University of Chicago Press

Stable URL: http://www.jstor.org/stable/10.1086/665012

Accessed: 24/07/2012 13:25

Your use of the JSTOR archive indicates your acceptance of the Terms \& Conditions of Use, available at http://www.jstor.org/page/info/about/policies/terms.jsp

JSTOR is a not-for-profit service that helps scholars, researchers, and students discover, use, and build upon a wide range of content in a trusted digital archive. We use information technology and tools to increase productivity and facilitate new forms of scholarship. For more information about JSTOR, please contact support@jstor.org. 


\section{HOGS GET SLAUGHTERED AT THE}

\section{SUPREME COURT}

Class action plaintiffs lost two major five-to-four cases last Term. Both will potentially have a significant negative impact on future litigation. The tragedy is that the impact of each of these cases might well have been avoided had the plaintiffs' lawyers, the lower courts, and the dissenting Justices not overreached. In this article, I show that the losing side insisted on broad and untenable positions and thereby set itself up for an equally broad defeat. Whether described in the poker vernacular of this essay's title ${ }^{1}$ or, in a more cultured phrasing, as hubris-in its original meaning of tempting the gods-the losing side got greedy and suffered the inevitable consequences. Unfortunately, in these cases, the consequences will redound to the detriment of many other potential litigants.

And these two cases are not isolated tragedies; they provide a window into a larger problem. Rule 23 turns class counsel into

Suzanna Sherry is Herman O. Loewenstein Professor of Law, Vanderbilt University Law School.

Author's nоте: I thank Lisa Bressman, Brian Fitzpatrick, Maria Glover, and Jay Tidmarsh for their helpful comments. Matt Meltzer provided excellent research assistance. This article was inspired by my late colleague, Richard Nagareda, from whom I learned so much. He will be missed.

${ }^{1}$ In poker, the expression is used to describe players with potentially winning hands who get too greedy and take risks that ultimately cause them to lose. Although the idiom has broader currency than at the poker table, it is a common sentiment there and is especially apt for a game in which players have a choice about exactly how much to risk at any given time. See Larry W. Phillips, The Tao of Poker: 285 Rules to Transform Your Game and Your Life 118 (Adams Media, 2003) (Rule 162, attributing it to a poker-room saying). 
powerful private attorneys general and tempts them to raise the stakes. It allows plaintiffs' lawyers to chart a course not only for their own clients, but for future litigants. If that course is ill-advised-as it is when the lawyers have incentives, as they often do, to frame issues broadly for the "big win"-the consequences can be disastrous for those future litigants. What this Term's cases demonstrate is that because we are unlikely to change the incentives of class counsel, we must instead focus on their ability to frame the issues. It is up to the courts, and especially to the judges most sympathetic to the interests of current and future class-action plaintiffs, to avoid the costs of lawyers' overreaching. That is exactly what the dissenting Justices (and the judges below) failed to do.

I begin with a discussion of AT\&T Mobility LLC $v$ Concepcion, ${ }^{2}$ in which the Court reversed the Ninth Circuit and upheld the enforceability of a contract in which consumers simultaneously agreed to arbitration and waived classwide arbitration. It seems likely that most consumer contracts will now contain such a clause, and classwide consumer actions - whether litigation or arbitration-will all but disappear. ${ }^{3}$ I then turn to Wal-Mart Stores, Inc. $v$ Dukes, ${ }^{4}$ in which the Court again reversed the Ninth Circuit, finding that a class consisting of all current and former female Wal-Mart employees should not have been certified. The likely effect of $\mathrm{Wal}$ Mart is not as certain as that of AT\&T Mobility, but there is a good possibility that the case will result in a ratcheting up of requirements for class certification and thus in fewer class actions, especially in the context of employment discrimination. I conclude by returning to the larger question of the appropriate judicial response to lawyers' overreaching.

\footnotetext{
2131 S Ct 1740 (2011).
}

${ }^{3}$ See Theodore Eisenberg, Geoffrey P. Miller, and Emily Sherwin, Arbitration's Summer Soldiers: An Empirical Study of Arbitration Clauses in Consumer and Nonconsumer Contracts, 41 U Mich J L Ref 871, 882-83 (2008) (observing that $80 \%$ of financial services and telecommunications consumer contracts contained class waivers in 2008). Professor Myriam Gilles predicted the "near-total demise" of the class action, partly because of contractual arbitration clauses, before the litigation in AT\&T Mobility even commenced. Myriam Gilles, Opting Out of Liability: The Forthcoming, Near-Total Demise of the Modern Class Action, 104 Mich L Rev 373 (2005). More recently-after AT\&T Mobility-she has written that "most class action cases will not survive the impending tsunami of class action waivers." Myriam Gilles and Gary Friedman, After Class: Aggregate Litigation in the Wake of AT\&T Mobility v. Concepcion, 79 U Chi L Rev (forthcoming 2012), available at http://ssrn.com/ abstract $=1928071$.

${ }^{4} 131 \mathrm{~S}$ Ct 2541 (2011). All nine Justices concurred in the result, and agreed on one ground for reversal. But on the most significant issue in the case-and the focus of this article-four Justices dissented. 


\section{AT\&T Mobility v Concepcion}

In $A T \nLeftarrow T$ Mobility, the majority reached the right result but for the wrong reasons. In this section, I suggest that different decisions by the plaintiffs' lawyers, the Ninth Circuit judges, or the dissenting Justices might have led to a narrower and less harmful opinion. I begin by describing and criticizing the majority's broad approach, and then turn to justifying the outcome of the case on narrower grounds.

\section{A. THE MAJORITY'S BROAD APPROACH}

Both the facts and the law in AT\&T Mobility made the plaintiffs' case unappealing. The Concepcions bought a phone from the defendant that had been advertised as "free," but were then charged about $\$ 30$ in taxes that state law required defendants to collect. The Concepcions challenged this as fraudulent advertising, a claim that in itself evokes images of litigation run amokit is not as if AT\&T Mobility (ATTM) could have declined to collect the tax. Nevertheless, they were entitled to make the claim, and to force ATTM to respond.

But it is bow the plaintiffs went about making the claim that led to the disastrous Supreme Court decision. The standard ATTM contract, signed by all phone purchasers, provided for arbitration of all disputes and mandated individual rather than classwide arbitration. The plaintiffs ${ }^{5}$ nevertheless filed a putative class action in federal court-on behalf of all consumers who had purchased a "free" or discounted phone as part of a "bundled" transactionagainst ATTM, ${ }^{6}$ raising various statutory and common-law California claims. The defendant moved to compel individual arbitration under the contract.

Plaintiffs' response to the motion to compel arbitration is the crux of the case: They argued that the class-arbitration waiver was unconscionable under California law and therefore unenforce-

${ }^{5}$ The Concepcions' complaint was consolidated with a putative class action filed by other plaintiffs, which had originally been filed in state court and removed to federal court by the defendant. See Laster $v$ AT\&T Mobility, 584 F3d 849, 853 (9th Cir 2009).

${ }^{6}$ The original defendant was Cingular Wireless, which was acquired by AT\&T and renamed. See id at $852 \mathrm{n} 1$. 
able. ${ }^{7}$ If (but only if) the waiver provision was unconscionable, then the courts had to decide whether the Federal Arbitration Act (FAA) preempts state-law doctrines of unconscionability.

The relevant substantive provision of the FAA is $\$ 2$, which provides:

A written provision in any ... [commercial] contract ... to settle by arbitration a controversy thereafter arising out of such contract ... shall be valid, irrevocable, and enforceable, save upon such grounds as exist at law or in equity for the revocation of any contract. ${ }^{8}$

Section 2 effectively embodies an implied preemption directive and an explicit savings clause wrapped into one. The Court has frequently reiterated that the FAA manifests a "liberal federal policy favoring arbitration." 9 To the extent that state law stands as an obstacle to this federal goal, it is preempted. But state laws that are generally applicable to all contracts - that is, grounds that "exist in law or equity for the revocation of any contract"-are saved from preemption.

Unconscionability, of course, is a general doctrine applicable to all contracts. The clear language of $\$ 2$ therefore suggests that the FAA does not preempt the invalidation of an arbitration clause found to be unconscionable, because the invalidation rests on grounds that exist for "the revocation of any contract." If contracts without arbitration clauses are sometimes found to be unconscionable-as of course they are-then unconscionability should fall within the savings clause. And, indeed, both the district court and the Ninth Circuit, after concluding that the class-arbitration waiver was unconscionable under California law, found no preemption.

A majority of the Supreme Court disagreed. To be fair, the Court was in something of a bind. If ATTM's carefully constructed ar-

\footnotetext{
7 The contract also contained a "blow-up" clause, declaring that if the class-arbitration ban were to be found unenforceable, the entire arbitration clause would be "null and void" and any class action would be litigated in court. Invalidation of the class-arbitration waiver thus effectively invalidated the arbitration clause. Brief for Respondent, AT\&T Mobility $L L C v$ Concepcion, Civil Action No 109-893, *3 (S Ct file, Sept 29, 2010) ("Respondent's Brief").

${ }^{8} 9$ USC $\$ 2$.

${ }^{9}$ Moses H. Cone Memorial Hospital v Mercury Construction Corp., 460 US 1, 24 (1983); see also Buckeye Check Cashing, Inc. v Cardegna, 546 US 440, 443 (2006) (noting that FAA embodies "national policy favoring arbitration").
} 
bitration clause is invalid, ${ }^{10}$ then $n o$ waiver of classwide arbitration will ever be valid. Given the strong pro-arbitration policy of the FAA - aggressively enforced by the Court in recent years ${ }^{11}$-as well as the legitimate reasons for a company to prefer one-on-one arbitration even if it is not trying to escape liability, ${ }^{12}$ invalidating all waivers of classwide arbitration no matter the circumstances is probably not the right result. The majority, however, did more than simply uphold the particular arbitration clause. Adopting a breathtakingly broad view of implied preemption, the Court held that "requiring the availability of classwide arbitration interferes with the fundamental attributes of arbitration and thus creates a scheme inconsistent with the FAA."13

The Court's analysis is vulnerable to several criticisms. First, the Court's reading of $\$ 2$ turns preemption doctrine on its head. In determining whether a federal statute preempts state law, the touchstone is always congressional intent. Moreover, federalism concerns dictate a presumption against preemption: "In all preemption cases, and particularly in those in which Congress has 'legislated ... in a field which the States have traditionally occupied,' we 'start with the assumption that the historic police powers of the States were not to be superseded by the Federal Act unless that was the clear and manifest purpose of Congress." 14

In the absence of either an express statutory statement preempting state law or unequivocal evidence that Congress intended to preempt state law, the Court looks at whether the state law in question would interfere with the purposes and objectives of the federal statute. That is a questionable endeavor, as several Justices have noted, because it is "potentially boundless." 15 This type of

\footnotetext{
${ }^{10}$ See text accompanying notes $42-46$ for an analysis of the special features of ATTM's arbitration clause.

${ }^{11}$ For a discussion of this trend, see Gilles, 104 Mich L Rev at 393-96 (cited in note 3). The trend has continued. See, for example, Stolt-Nielsen SA v AnimalFeeds International Corp., 130 S Ct 1758 (2010); Rent-a-Center West v Jackson, 130 S Ct 2772 (2010).

${ }^{12}$ See text accompanying notes 55-68 for a discussion of these reasons.

${ }^{13} 131 \mathrm{~S} \mathrm{Ct}$ at 1748.

${ }^{14}$ Medtronic Inc. v Lohr, 518 US 470, 485 (1996) (citation omitted), quoting Rice v Santa Fe Elevator Corp., 331 US 218, 230 (1947). See also Wyeth v Levine, 129 S Ct 1187, 1195 n 3 (2009); Altria Group, Inc. v Good, 555 US 70, 76 (2008); Bates v Dow Agrosciences LLC, 544 US 431, 449 (2005).

${ }^{15}$ Geier v American Honda Motor Co., 529 US 861, 907 (2000) (Stevens, J, dissenting); see also Wyeth $v$ Levine, $129 \mathrm{~S}$ Ct at 1207 (Thomas, J, concurring in judgment); Pharmaceutical Research of Manufacturers of America v Walsh, 538 US 644, 678 (2003) (Thomas,
} 
implied preemption should therefore be cabined-and rare-even for statutes that contain no savings clause. But the AT\&T Mobility majority went even further than ordinary purposes-and-objectives implied preemption: It found such preemption in the face of an express savings clause. Only once before-and in a much narrower context-has the Court ever overridden an express savings clause by finding implied preemption. ${ }^{16}$ Doing so is inconsistent with both the presumption against preemption and the goal of implementing congressional intent.

Second, the Court read into the FAA a particular approach to implied preemption that is inconsistent with the statutory language. The FAA saves from preemption "such grounds as exist ... for the revocation of any contract." The AT\&T Mobility majority recognized that California unconscionability law applies equally to waivers of class arbitration and waivers of class litigation, and is thus "a doctrine normally thought to be generally applicable." ${ }^{17}$ It nevertheless concluded that even a generally applicable state-law doctrine is preempted if it is "applied in a fashion that disfavors arbitration." 18

The majority gave as examples of laws "applied in a fashion that disfavors arbitration" hypothetical state laws conditioning enforceability of arbitration clauses on the availability of judicially monitored discovery or on the application of the Federal Rules of Evidence, and found the availability of classwide arbitration to be similar. ${ }^{19}$ These examples-as well as the Court's analysis of how a requirement of class arbitration interferes with the purposes of arbitration $^{20}$ - suggest that the majority did not mean to focus on instances in which state (or federal) courts apply the same doctrines differentially in cases that involve arbitration clauses and cases that do not, because all of the examples supplied by the majority (including the classwide arbitration at issue in AT\&T Mobility) seem to assume that the doctrine will be applied equally in all cases.

Instead, the majority seems to have had in mind a concept anal-

J, concurring in judgment); Crosby v National Foreign Trade Council, 530 US 363, 388-91 (2000) (Scalia, J, concurring in judgment).

${ }^{16}$ See Geier, 529 US at 861 (2000).

${ }^{17} 131 \mathrm{~S} \mathrm{Ct}$ at 1747.

${ }^{18} \mathrm{Id}$.

${ }^{19}$ Id at $1747-48$.

${ }^{20} \mathrm{Id}$ at 1751-52. For further discussion of that analysis, see text accompanying notes 21-25. 
ogous to disparate impact. Although unconscionability applies identically in all cases to invalidate certain limitations on classwide dispute resolution, it disproportionately invalidates arbitration contracts because they are inherently more likely to run afoul of the requirements. Similarly, a requirement that all enforceable contracts provide for the use of discovery or evidence rules will disproportionately invalidate arbitration contracts. Another way to put it is to suggest that these sorts of requirements will have a disparate impact on arbitration generally, by influencing contracting parties to prefer litigation.

But neither the language nor the purpose of the FAA justifies importing a disparate impact principle into the savings clause. The unconscionability principle is a "ground[] . . f for the revocation of any contract"; its application is not limited, in principle or in fact, to agreements to arbitrate. As for purposes, the FAA was enacted primarily to counter state (and federal) hostility to arbitration: "the basic purpose of the Federal Arbitration Act is to overcome courts' refusal to enforce agreements to arbitrate." ${ }^{21}$ It therefore should not be read to preempt a neutral state doctrinelike unconscionability-unless the purpose of that doctrine was to diminish the enforceability of arbitration clauses. The Court was mistaken to compare unconscionability to hypothetical state law requirements that juries be used, that judicially supervised discovery be allowed, or that the Federal Rules of Evidence be followed, because those requirements would be obvious pretexts, designed to prevent arbitration. But there is no evidence that California's doctrine of unconscionability was in any way motivated by hostility toward arbitration.

In fact, the first case in which a California court found the unavailability of classwide dispute resolution unconscionable was America Online, Inc. $v$ Superior Court, ${ }^{22}$ which involved class actions rather than class arbitration. The court found the "unavailability of class action relief ... in and by itself sufficient to preclude enforcement" of a consumer contract. ${ }^{23}$ Four years later, the Cal-

\footnotetext{
${ }^{21}$ Allied-Bruce Terminix Companies v Dobson, 513 US 265, 270 (1995).

2290 Cal App 4th 1, 108 Cal Rptr 2d 699 (Cal Ct App 2001).

${ }^{23} 90 \mathrm{Cal}$ App 4th at 18, $108 \mathrm{Cal}$ Rptr $2 \mathrm{~d}$ at 713 . The contractual provision at issue was a forum-selection clause, but because the forum specified by the contract did not permit consumer class actions, the court found it to be the "functional equivalent" of a class-action waiver. $90 \mathrm{Cal} \mathrm{App} \mathrm{4th} \mathrm{at} \mathrm{5,} 108 \mathrm{Cal} \mathrm{Rptr} \mathrm{2d} \mathrm{at} 702$.
} 
ifornia Supreme Court relied in part on America Online when it held, in Discover Bank $v$ Superior Court, that exculpatory waivers of either class actions or class arbitration are unconscionable. ${ }^{24}$ Other California courts have also applied the Discover Bank doctrine to class-action waivers in contracts without arbitration clauses. ${ }^{25}$ In light of the absence of any deliberate attempt to disadvantage or limit arbitration contracts, the majority's holding that the FAA preempts neutral, generally applicable California unconscionability doctrines because of their effect on arbitration clauses is a misreading of the federal statute.

Finally, the majority turns its back on a recent, directly relevant case, without so much as a citation to it. In the course of its purposes-and-objectives analysis, the majority suggested that classwide arbitration interferes with the goals of the FAA because of the "fundamental" differences between classwide and bilateral arbitration. ${ }^{26}$ In particular, the Court reasoned, "class arbitration greatly increases the risks to defendants" because the "higher stakes of class litigation" will cause defendants to be "pressured into settling questionable claims." ${ }^{27}$ But just the previous Term, in Shady Grove Orthopedic Associates $v$ Allstate Insurance Co. ${ }^{28}$ a majority that included three members of the AT\&T Mobility majority held that class litigation did not fundamentally differ from bilateral litigation. Rejecting the defendant's argument that allowing class litigation "transform[s] the dispute over a five bundred dollar penalty into a dispute over a five million dollar penalty," the Court in Shady Grove described the threat of greater liability as just an "incidental effect" of the availability of a class action. ${ }^{29}$ The

${ }^{24} 113$ P3d 1100, 1106-07, 1108 (2005). The Ninth Circuit ruling reversed by $A T \& T$ Mobility also relied on Discover Bank.

${ }^{25}$ See, for example, In re Yahoo! Litigation, 251 FRD 459 (CD Cal 2008); Elhiluv Quiznos Franchise Co., LLC, No 06-CV-07855 (CD Cal April 3, 2008). Courts in other states have also refused to enforce class-action waivers (or forum-selection clauses with the same effect) in nonarbitration cases. See, for example, Dix v ICT Group, Inc., 161 P3d 1016 (Wash 2007); America Online, Inc. v Pasieka, 870 S2d 170 (Fla Ct App 2004).

${ }^{26} 131 \mathrm{~S} \mathrm{Ct}$ at 1750 , quoting Stolt-Nielsen, $130 \mathrm{~S} \mathrm{Ct}$ at 1776.

${ }^{27} 131 \mathrm{~S} \mathrm{Ct}$ at 1752 . The Court also pointed to the fact that class arbitration might slow down the dispute-resolution process and the fact that class arbitration requires procedural formality. Id at 1751 . As the dissent points out, the Court has previously upheld state-law requirements that have each of these effects. See id at 1761 (Breyer, J, dissenting).

${ }^{28} 130$ S Ct 1431 (2010).

${ }^{29}$ Id at 1443 . The Shady Grove plurality-which largely overlapped the AT\&T Mobility majority, with both opinions written by Justice Scalia - may have been concerned about a possible tension with the Rules Enabling Act, 28 USC $\$ 2072$. If bringing claims as a 
class action in Shady Grove and class arbitration in AT\&T Mobility both increased the stakes for the defendant in the same way, creating what the latter case labeled a "risk of 'in terrorem' settlements." ${ }^{30}$ One would therefore expect the AT\&T Mobility Court to follow, or at least to distinguish explicitly, Shady Grove in its analysis of whether classwide and bilateral dispute resolution are so fundamentally different that class arbitration interferes with the purposes of arbitration. ${ }^{31}$ It did not do so.

\section{B. THE ROAD NOT TAKEN}

On the preemption question, then, the dissent has the better of the argument: The FAA should not be interpreted to preempt California's neutral, generally applicable unconscionability doctrine. But that does not necessarily mean that the class-arbitration waiver in this case should have been invalidated. Indeed, given pragmatic concerns that I will address shortly, AT\&T Mobility's waiver (but not all such waivers) should be enforceable. The problem is that once the issue was joined on preemption rather than enforceability vel non, the majority seemed unable to refrain from issuing broad pronouncements on preemption in general, and preemption of unconscionability doctrines in particular. But while the majority might have been a bit more restrained, more of the fault lies with the other side. The majority would not have addressed preemption at all, but for the insistence of the plaintiffs' lawyers, the lower federal courts, and the dissenting Justices that the classarbitration waiver was unconscionable. ${ }^{32}$ It is that insistence, I

class action has more than an incidental effect on substantive rights, then Rule 23 might be invalid. Regardless, the difference between class litigation and individual litigation should be analyzed the same way in Shady Grove and Concepcion. For further discussion of the limits on procedural rules, see note 68 .

${ }^{30} 131 \mathrm{~S} \mathrm{Ct}$ at 1752.

${ }^{31}$ The late Professor Richard Nagareda suggested that Shady Grove supported reversal of the Ninth Circuit. See Richard Nagareda, The Litigation-Arbitration Dichotomy Meets the Class Action, 86 Notre Dame L Rev 1069 (2011). His analysis, however, turns on his assumption that California unconscionability law is based on a state law policy that seeks to "confron $[\mathrm{t}]$. . . the defendant with the full force of class-wide deterrence." Id at 1121. In Section IB, I take issue with that assumption.

${ }^{32}$ Indeed, the plaintiffs explicitly urged the Supreme Court to "decline AT\&T's invitation" to decide the case on the basis of state law. Respondent's Brief at *12. Although ATTM did not explicitly ask the Supreme Court to rule on the state-law question, its brief repeatedly denigrated the Ninth Circuit's interpretation of California unconscionability law as "a new rule," a "wildly idiosyncratic interpretation," "novel," and a "plainly discriminatory application of California's unconscionability principles." See Brief for Petitioner, AT\&T Mobility LLC v Concepcion, No 09-893, 19, 36, 43 (S Ct, filed Aug 2, 2010) 
contend, that constitutes the hubris (or the greediness for a big win) that ultimately led to the majority's broad ruling. We can blame the majority for its poor legal analysis and the unnecessary breadth of the opinion. But given the lawyers' arguments, the disastrous consequences of invalidating this class-arbitration waiver clause (one of the most consumer-friendly such clauses imaginable), and the Court's previous strong support for arbitration generally, it was the dissenters who had the last clear chance to rescue the situation.

Arguments about the preemptive effect of the FAA are only relevant if the contract is in fact unconscionable under state law. The plaintiffs claimed that it was, and both the district court and the Court of Appeals explicitly agreed. The Supreme Courtincluding the dissenters-took those courts' word for it without comment. Had they not, the result might have been very different, because if the contract was not unconscionable there was no need to decide any preemption questions. And an examination of the context of the California Supreme Court decision in Discover Bank, on which the lower courts relied, demonstrates that those courts misapplied California law when they concluded that the ATTM contract was unconscionable. The whole mess might have been avoided if this issue and not the big win were the focus of the case.

How should the issue have been more modestly framed and resolved? Let us begin with basic unconscionability doctrine. Courts considering previous generations of class-arbitration waivers had invalidated them as unconscionable because they were exculpatory-they placed such onerous burdens on complaining consumers that no individual consumer would ever seek arbitration, and thus the corporate defendants could engage in unlawful conduct with impunity. The first generation of class-arbitration waivers were truly unconscionable, as "avaricious drafters included terms that excluded punitive damages and incidental or conse-

("Petitioner's Brief"). Perhaps ATTM failed to make the state-law argument more explicit because it, too, was greedily hoping for a broad federal-law win rather than a narrow state-law one. But the potential downside for ATTM was much lower: Had the Court rejected the preemption argument, ATTM could still have argued to other courts (both state and federal) that its particular contract was not unconscionable; only in the Ninth Circuit would that argument have been foreclosed. And, of course, California state courts would not be bound by the Ninth Circuit's interpretation of California law, so ATTM might have been able to undo even that damage. ATTM was therefore not risking as much as the plaintiffs were by downplaying the state-law grounds for reversal. 
quential damages, prohibited attorneys fees, required the arbitration to proceed in a location far from the consumer's home, required the consumer to pay half or sometimes all of the arbitration fees, imposed mandatory confidentiality clauses, or gave the drafter the sole capability of selecting the arbitrator." ${ }^{33}$

Responding to multiple courts' invalidation of such contractual terms as unconscionable ${ }^{34}$ the second generation of class-arbitration waivers omitted all these punitive provisions and allowed consumers to bring individual claims at a relatively low cost. The problem, however, was that imposing any monetary cost (in addition to the expenditure of the consumer's time and energy) served as a disincentive for consumers-or attorneys, even if their fees would be paid-with very small claims. Recall that the Concepcions' claim was for \$30: No individual would be willing to take that individual claim to arbitration if the only pay-out was $\$ 30$; and the award of attorney's fees to a prevailing party, without some premium for the risk of losing, would be insufficient to motivate most attorneys. Some courts therefore held these secondgeneration waivers unconscionable as well. ${ }^{35}$

The California Supreme Court's decision in Discover Bank addressed one of these second-generation waivers. The court explained the problem with such waivers, quoting Szetela $v$ Discover Bank: ${ }^{36}$

Fully aware that few customers will go to the time and trouble of suing in small claims court, Discover has instead sought to create for itself virtual immunity from class or representative actions despite their potential merit, while suffering no similar detriment to its own rights. ... The clause is not only harsh and unfair to Discover customers who

${ }^{33}$ Ramona L. Lampley, Is Arbitration Under Attack? Exploring the Recent fudicial Skepticism of the Class Arbitration Waiver and Innovative Solutions to the Unsettled Legal Landscape, 18 Cornell J L \& Pub Pol 477, 503-04 (2009). Professor Lampley's excellent article canvasses the three generations of class arbitration waivers. For a history of the development of the first generation of waivers, see Gilles, 104 Mich L Rev at 396-99 (cited in note 3).

${ }^{34}$ See Lampley, 18 Cornell J L \& Pub Pol at 504 n 131 (cited in note 33); Gilles, 104 Mich L Rev at 399-400 \& n 136 (cited in note 3); Paul Carrington, Unconscionable Laywers, 19 Ga St U L Rev 361, 373-80 (2002).

${ }^{35}$ In addition to Discover Bank, see, for example, Kristian v Comcast Corp., 446 F3d 25 (1st Cir 2006); Scott v Cingular Wireless, 161 P3d 1000 (Wash 2007); Kinkel v Cingular Wireless LLC, 857 NE2d 250 (Ill 2006). See also Jean R. Sternlight, As Mandatory Binding Arbitration Meets the Class Action, Will the Class Action Survive? 42 Wm \& Mary L Rev 1, 80 (2000) ("no one has seriously suggested that arbitration ensures an economically viable forum for persons with claims of five dollars, ten dollars, or even two hundred dollars ... [because] the minimum filing fee will exceed the size of a small claim").

3697 Cal App 4th 1094, 1101, 118 Cal Rptr 2d 862, 867-68 (Cal App 2002). 
might be owed a relatively small sum of money, but it also serves as a disincentive for Discover to avoid the type of conduct that might lead to class action litigation in the first place... The potential for millions of customers to be overcharged small amounts without an effective method of redress cannot be ignored. ${ }^{37}$

This passage illustrates the problem with second-generation class arbitration waivers: Very small claims, however meritorious, are unlikely to be brought, and the bank is therefore free to engage in unlawful conduct that makes millions of dollars for the bank but that costs each consumer very little. As one commentator put it, a class arbitration waiver of this kind allows businesses "to engage in unchecked market misbehavior that results in small and seemingly insignificant consequences upon individuals, but which leads to sizeable windfalls for the particular corporation in the aggregate." 38

The Discover Bank court, however, was careful to limit its holding: "We do not hold that all class action waivers are necessarily unconscionable." It invalidated only "waiver[s] . . . found in a consumer contract of adhesion in a setting in which disputes between the contracting parties predictably involve small amounts of damages ... when it is alleged that the party with the superior bargaining power has carried out a scheme to deliberately cheat large numbers of consumers out of individually small sums of money." 39

Discover Bank, like the other cases invalidating second-generation waivers, also found no preemption. ${ }^{40}$ Because the unconscionability doctrine applied to all exculpatory contracts, not just to arbitration clauses, the FAA savings clause protected it from preemption. The fact that the Supreme Court did not grant certiorari in any of these earlier cases ${ }^{41}$ suggests that it was content to allow the unconscionability doctrine and the FAA to coexist.

AT\&T Mobility's contract, however, was different. It contained a third-generation arbitration clause. This clause did more than simply require arbitration and waive classwide arbitration: It set

\footnotetext{
${ }^{37} 113 \mathrm{P} 3 \mathrm{~d}$ at $1107-08$.

${ }^{38}$ J. Maria Glover, Note, Beyond Unconscionability: Class Action Waivers and Mandatory Arbitration Agreements, 59 Vand L Rev 1735, 1747 (2006).

${ }^{39} 113 \mathrm{P} 3 \mathrm{~d}$ at 1110 .

${ }^{40} \mathrm{Id}$ at $1110-17$.

${ }^{41}$ See Nagareda, 86 Notre Dame L Rev at 1106 (cited in note 31).
} 
up a complicated structure that was designed both to enable small claims and to channel them into bilateral arbitration. Responding to some of the problems with first-generation waiver clauses, the ATTM contract provided that ATTM would pay the cost of arbitration unless an arbitrator determined that the claim was frivolous; allowed consumers to choose arbitration in person (in the consumer's home county), by telephone, or through documentary evidence; and allowed the arbitrator to award any remedy including injunctive relief, punitive damages, and attorneys' fees. ${ }^{42}$

More importantly, the ATTM contract also rectified the problems with second-generation waivers by offering premiums to successful consumers and their attorneys. It provided that if the arbitrator awarded more than ATTM's last written settlement offer, ATTM would pay the jurisdictional maximum of the small claims court in the consumer's jurisdiction-which in California is $\$ 7,500$-if that amount was larger than the arbitrator's award. ${ }^{43}$ It also provided that if the arbitral award was larger than ATTM's last settlement offer, ATTM would pay double the attorneys' fees. ${ }^{44}$ Finally, it provided for streamlined procedures, with relevant information and documents available on ATTM's website. ${ }^{45}$ The district court concluded that the contractually mandated arbitration process was "quick, easy to use, and prompts full or, as described by Plaintiffs, even excess payment to the customer without the need to arbitrate or litigate." ${ }^{\circ 6}$

Such a clause is not exculpatory and therefore should not be unconscionable under Discover Bank. The incentive structure gives consumers a reason to pursue small individual claims and ATTM a reason to settle such claims fairly. Even an individual consumer with a small claim has an incentive to mail in the one-page Notice of Dispute form that is posted on the ATTM website ${ }^{47}$ (which is surely no more onerous than consulting an attorney to initiate a class action). By filing such a claim, the consumer can anticipate

${ }^{42}$ See Laster v T-Mobile USA, Inc., 2008 WL 5216255 at *2-3 \& n 2 (SD Cal Aug 11, 2008), aff'd, Laster $v$ AT $\mho T$ Mobility LLC, 584 F3d 849 (9th Cir 2009), rev'd, AT $\nleftarrow T$ Mobility v Concepcion, 131 S Ct 1740 (2011).

${ }^{43}$ Id at *2.

${ }^{44} \mathrm{Id}$.

${ }^{45}$ Id at *3.

${ }^{46} \mathrm{Id}$ at ${ }^{*} 11$.

${ }^{47}$ Id at *3. 
either a prompt and reasonable settlement offer or a windfall if an arbitrator ultimately finds the settlement offer inadequate. And ATTM has every incentive to offer an appropriate amount in settlement, rather than insist on arbitration, in order to avoid the penalties that attach if an arbitrator ultimately awards more than the settlement offer. ${ }^{48}$ The waiver clause is thus not exculpatory because it does not allow ATTM to "cheat large numbers of consumers out of individually small sums of money."

The Ninth Circuit essentially conceded that ATTM had an incentive to settle all disputes for reasonable amounts. The problem, according to that court, was somewhat different:

The provision does essentially guarantee that the company will make any aggrieved customer whole who files a claim. Although this is, in and of itself, a good thing, the problem with it under California lawas we read that law-is that not every aggrieved customer will file a claim. ${ }^{50}$

Similarly, the district court was troubled by the premium provisions because they "prompt[ed] ATTM to accept liability, rather than 'escape liability,' for small dollar claims." "In other words, the problem was not that the contract created "a disincentive for [defendant] to avoid the type of conduct that might lead to class action litigation in the first place," but that it did not create sufficient incentive to avoid that conduct because some aggrieved consumers might not file claims.

But think about the most likely reasons a consumer would not file a claim: Either she concludes that the burden of filing a claim outweighs the harm she has suffered, or she is unaware that she has suffered any harm at all. Given the ease of claim filing under the AT\&T Mobility contract, the first possibility seems unlikely. Resting a finding of unconscionability on the second possibility requires a conclusion that we ought to deter conduct that is not

${ }^{48}$ Not only does ATTM have an incentive to offer an adequate settlement, but one study suggests that a party making a written settlement offer is less likely to err in its calculation of the ultimate worth of a claim as found by a court or an arbitrator. See Randall L. Kiser, Martin A. Asher, and Blakely B. McShane, Let's Not Make a Deal: An Empirical Study of Decision Making in Unsuccessful Settlement Negotiations, $5 \mathrm{~J}$ Empirical Leg Stud 551, 572-74 (2008).

${ }^{49}$ Discover Bank, 113 P3d at 1110. Professor Lampley offered a similar analysis prior to the AT\&T Mobility litigation. See Lampley, 18 Cornell J L \& Pub Pol at 513-17 (cited in note 33$)$.

${ }^{50}$ Laster, $584 \mathrm{~F} 3 \mathrm{~d}$ at $856 \mathrm{n} 9$.

${ }^{51}$ Laster, 2008 WL 5216255 at * 10. 
perceived as harmful by the person it supposedly harms. While that conclusion may be warranted in rare cases-perhaps where the target is especially vulnerable-it seems a poor basis on which to invalidate a broad range of consumer contracts. And under either possibility, it seems contrary to our underlying principle of litigant autonomy to argue that legal doctrines should entice people into litigation rather than simply removing any barriers that inhibit them from suing. ${ }^{52}$

The AT\&T Mobility contract is thus a far cry from the secondgeneration waivers found exculpatory in Discover Bank on the basis that it would not be worthwhile for any aggrieved consumer to pursue arbitration. ${ }^{53}$ The lower courts' assumption that the availability of classwide resolution provides significantly more deterrence thus ends up resting on the most likely monetary difference between classwide and bilateral dispute resolution: the ratcheting up of attorneys' fees as a percentage of the settlement. ${ }^{54}$

But if a third-generation arbitration clause like that in the ATTM contract is not exculpatory, why would a company include one, and why would plaintiffs-or their lawyers-object? Understanding the answers to those questions might help explain why the plaintiffs overreached. The key lies in the effect of aggregating multiple individual claims into a single classwide suit or arbitration proceeding.

There is great dispute about whether a "hydraulic pressure ... to settle" 55 actually causes defendants to settle class actions for more than they are worth on their merits. ${ }^{56}$ The most persuasive

${ }^{52}$ This question also implicates the relationship between substance and procedure, which is beyond the scope of this article. See note 68 .

${ }^{53}$ Professor Nagareda identified the crux of the difference as that between exculpation and suboptimal deterrence, 86 Notre Dame L Rev at 1118-19 (cited in note 31). He suggested that the lower courts in AT\&T Mobility were implementing a state-law policy in favor of "confronting . . . a defendant with the full force of class-wide deterrence," and that such a policy cannot trump federal law. Id at 1121. My argument is that state-law policy, as enunciated in Discover Bank, does not in fact embody a preference for full-force deterrence; the federal courts were mistaken in thinking that it did.

${ }^{54}$ See text accompanying notes 67-68.

${ }^{55}$ Newton v Merrill Lynch, 259 F3d 154, 164 (3d Cir 2011).

${ }^{56}$ Compare Henry Friendly, Federal furisdiction: A General View 119-20 (Columbia, 1973) (aggregation "blackmails" defendants into settling); Richard A. Epstein, Class Actions: Aggregation, Amplification, and Distortion, 2003 U Chi Legal F 457 (examining distortion effect of class actions); Alan S. Kaplinsky and Mark J. Levin, Excuse Me, but Who's the Predator: Banks Can Use Arbitration Clauses as a Defense, 7 Bus L Today 24 (May-June 1998) ("companies often feel pressured to pay substantial amounts in settlement for reasons having nothing to do with the actual merits of the dispute"), with Charles Silver, "We're 
argument that aggregation distorts settlement values is that it increases the variance, leading risk-averse defendants ${ }^{57}$ to settle even low-probability or unmeritorious claims. Consider the situation in In re Rbone-Poulenc Rorer Inc., ${ }^{58}$ probably the most famous example of a judge declining to certify a class because of the likely settlement pressure exerted by certification. In Rbone-Poulenc, Judge Posner estimated-based on prior individual trials-that plaintiffs had approximately an 8 percent chance of prevailing. ${ }^{59}$ He noted a concern with "forcing these defendants to stake their companies on the outcome of a single jury trial." ${ }^{60}$ As Professor Richard Nagareda has explained, Judge Posner was concerned about the variance, or "amplification effect" of aggregation. ${ }^{61}$ If liability determinations were spread out over one thousand individual trials, the great likelihood was that the defendants would indeed lose about 8 percent of the cases, and pay out 8 percent of the claimed damages. Perhaps they would lose 5 percent or 15 percent, but the variance would still be small. If, instead, liability was determined in a single class action, the defendants faced a 92 percent chance of paying nothing and an 8 percent chance of having to pay 100 percent of the claimed damages. Although the expected value is the same under both scenarios, the variance has increased dramatically, and-given risk aversion-so has the pres-

Scared to Death": Class Certification and Blackmail, 78 NYU L Rev 1357 (2003) (suggesting that class actions are rarely if ever inappropriately threatening); Bruce Hay and David Rosenberg, "Sweetheart" and "Blackmail" Settlements in Class Actions: Reality and Remedy, 75 Notre Dame L Rev 1377 (2000) (suggesting that few class actions are blackmail). See also William B. Rubenstein, Why Enable Litigation? A Positive Externalities Theory of the Small Claims Class Action, 74 UMKC L Rev 709 (2006) (arguing aggregation and the resulting settlement pressure causes positive externalities).

${ }^{57}$ Defendants as a group tend to be more risk-seeking than risk-averse, see Jeffrey J. Rachlinski, Gains, Losses, and the Psychology of Litigation, 70 S Cal L Rev 113 (1996), but the typical aggregation scenario makes them more risk-averse in two ways. First, the uncertainty caused by a large variance induces defendants to behave in risk-averse fashion. See Joseph A. Grundfest and Peter H. Huang, The Unexpected Value of Litigation: A Real Options Perspective, 58 Stan L Rev 1267 (2006). Second, risk-seeking defendants and riskaverse plaintiffs switch attitudes when confronting low-probability claims. See Chris Guthrie, Framing Frivolous Litigation: A Psychological Theory, 67 U Chi L Rev 163 (2000). As one scholar put it, "[r]isk aversion comes naturally to defendants facing mass litigation." Howard M. Erichson, Uncertainty and the Advantage of Collective Settlement, 60 DePaul L Rev 627, 636 (2011).

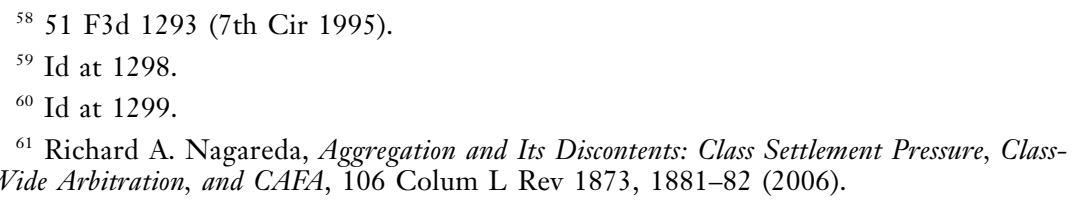


sure to settle. ${ }^{62}$ Aggregation, by increasing the risk to defendants, increases their incentive to "offload" that risk by offering a settlement that includes a premium. ${ }^{63}$

If aggregation (whether in litigation or arbitration) has this effect, we can understand why defendants would favor, and plaintiffs would disfavor, waivers of classwide arbitration. But a waiver by itself (that is, a typical second-generation arbitration clause) also has the effect of excusing liability altogether. A second-generation waiver, therefore, does not tell us whether the defendant is trying to avoid liability altogether or simply to avoid being put in a position where it might have to overcompensate plaintiffs for conceded liability.

That is where the third-generation arbitration clause comes in. An arbitration clause like ATTM's is designed-as the district court noted-to cause the defendant to "accept liability" by making it easy for consumers to make claims and expensive for the defendant to refuse to adequately compensate meritorious claimants. But at the same time, the clause precludes plaintiffs from using the pressure of a class action to demand excessive compensation. The third-generation clause, especially as a development after the invalidation of second-generation clauses, removes the ambiguity about the defendant's motives: Rather than trying to avoid liability altogether, the defendant is simply trying to ensure that plaintiffs will obtain only the compensation for which ATTM is liable and not the overcompensation that might be extracted based on the increase in variance. ${ }^{64}$

Another aspect of the distortive effect of aggregation provides

${ }^{62}$ A second reason that aggregation increases the pressure to settle is that it simply increases the likely number of claims. As several scholars have suggested, this is not a valid argument against class treatment-if the claims are meritorious, we ought to encourage them and remove any barriers to filing them. See, for example, Nagareda, 106 Colum L Rev at 1882-85 (cited in note 61); Silver, 78 NYU L Rev at 1365-69 (cited in note 56). But see Andrew T. Berry, Comments on Aggregation: Some Unintended Consequences of Aggregative Disposition Procedures, 31 Seton Hall L Rev 920, 921-22 (2001) (suggesting that defendants are likely to settle large class actions for accounting reasons rather than because of their likely liability).

${ }^{63}$ See Richard Nagareda, 1938 All Over Again? Pretrial as Trial in Complex Litigation, 60 DePaul L Rev 647, 668-69 (2011); see also Jonathan T. Molot, A Market in Litigation Risk, 76 U Chi L Rev 367 (2009).

${ }^{64}$ Moreover, to the extent that showing unconscionability under Discover Bank requires "a scheme to deliberately cheat large numbers of consumers," 113 P3d at 1110 , the Concepcion class seems particularly ill-suited to claim unconscionability. After all, the tax money that was collected on the "free" phone went straight to the state. 
a second insight into the ATTM arbitration clause. The conventional justification for class actions for damages under Rule 23(b)(3) - as opposed to "limited fund" class actions under Rule 23(b)(1) or suits seeking injunctive or declaratory relief under Rule 23(b)(2) - is that it removes barriers to suit that would otherwise exist for small, unmarketable claims. ${ }^{65}$ This justification diminishes or backfires when small claims are marketable. For example, when the legislature has provided for minimum statutory damages in order to ensure that plaintiffs with small actual damages will still be likely to bring suit, a class action may be described as overkill. One court described the issue as

aris[ing] from the effects of combining a statutory scheme that imposes minimum statutory damages awards on a per-consumer basis-usually in order to encourage the filing of individual lawsuits as a means of private enforcement of consumer protection laws-with the class action mechanism that aggregates many claims-often because there would otherwise be no incentive to bring an individual claim. Such a combination may expand the potential statutory damages so far beyond the actual damages suffered that the statutory damages come to resemble punitive damages - yet ones that are awarded as a matter of strict liability, rather than for the egregious conduct typically necessary to support a punitive damages award. It may be that the aggregation in a class action of large numbers of statutory damages claims potentially distorts the purpose of both statutory damages and class actions. If so, such a distortion could create a potentially enormous aggregate recovery for plaintiffs, and thus an in terrorem effect on defendants, which may induce unfair settlements. ${ }^{66}$

The ATTM premium provisions-which give plaintiffs and their attorneys incentives to file small claims-operate similarly to statutory damages provisions. And, analogously, the availability of

${ }^{65}$ See, for example, Eisen v Carlisle \& Facquelin, 417 US 156, 161 (1974) ("Economic reality dictates that [a suit involving a $\$ 70$ claim] proceed as a class action or not at all."); Phillips Petroleum Co. v Shutts, 472 US 797, 809 (1985) ("Class actions . . may permit the plaintiffs to pool claims which would be uneconomical to litigate individually."); $A m$ chem Prods, Inc. $v$ Windsor, 521 US 591, 617 (1997) ("The policy at the very core of the class action mechanism is to overcome the problem that small recoveries do not provide the incentive for any individual to bring a solo action prosecuting his or her rights.").

${ }^{66}$ Parker v Time Warner Entertainment Co., 331 F3d 13, 22 (2d Cir 2003). See also J. Maria Glover, The Structural Role of Private Enforcement in Public Law, 53 Wm \& Mary L Rev 1137 (forthcoming 2012) (calling the combination of statutory damages and class actions "remedial overkill"). As Professor Stephen Burbank put it in a posting on the Civil Procedure Listserv, "most of the pain that opponents of the modern class action have felt has been where, from the perspective of private enforcement, Rule 23 acts as a wild-card, trans-substantively raising the stakes without regard to congruence with the goals of substantive law." 
class arbitration magnifies the effect of the premiums. Thus a third-generation arbitration clause, offering premiums but waiving class arbitration, serves as choice between two alternative methods of removing barriers for low-value claims. While consumers might prefer one method over the other, inclusion of the premium provisions strongly suggests that the corporation is not attempting to avoid liability.

Finally, even if the classwide nature of the dispute-resolution process does not itself cause defendants to settle unmeritorious claims, or to settle meritorious claims for more than their objective worth, another aspect of class arbitration might. It is well known that class actions-especially those involving small claims-are driven less by the class members (even the named class representative) and more by entrepreneurial lawyers. ${ }^{67}$ Those lawyers, however, may reap significantly greater fees from class actions than they might from a series of individual suits, at least where the claims are small. One scholar has suggested that in a large percentage of damages class actions, "attorneys [are] effectively the sole beneficiaries." ${ }^{68}$ It is therefore reasonable for a potential de-

${ }^{67}$ For a classic description of this regime, see John C. Coffee, Jr., Understanding the Plaintiff's Attorney: The Implications of Economic Theory for Private Enforcement of Law Through Class and Derivative Actions, 86 Colum L Rev 669 (1986); see also John C. Coffee, Jr., The Regulation of Entrepreneurial Litigation: Balancing Fairness and Efficiency in the Large Class Action, 54 U Chi L Rev 877 (1987); Jonathan R. Macey and Geoffrey P. Miller, The Plaintiffs' Attorney's Role in Class Action and Derivative Litigation: Economic Analysis and Recommendations for Reform, 58 U Chi L Rev 1 (1991); Martin H. Redish, Class Actions, Litigation Autonomy, and the Foundations of Procedural Due Process, 95 Cal L Rev 1573 (2007).

${ }^{68}$ Martin H. Redish, Wholesale fustice: Constitutional Democracy and the Problem of the Class Action Lawsuit 15 (Stanford, 2009). See also John H. Beisner, Matthew Shors, and Jessica D. Miller, Class Action "Cops": Public Servants or Private Entrepreneurs? 57 Stan L Rev 1441 (2005); Jill E. Fisch, Class Action Reform, Qui Tam, and the Role of the Plaintiff, 60 L \& Contemp Probs 167 (1997); Susan P. Koniak and George M. Cohen, Under Cloak of Settlement, 82 Va L Rev 1051 (1996); Jay Tidmarsh, Pound's Century, and Ours, 81 Notre Dame L Rev 513 (2006); Charles Wolfram, Mass Torts-Messy Ethics, 80 Cornell L Rev 1228 (1995).

Some scholars have argued that despite the absence of benefit to class members, class actions are socially beneficial because they "caus[e] the defendant-wrongdoer to internalize the social costs of its actions." Myriam Gilles and Gary B. Friedman, Exploding the Class Action Agency Costs Myth: The Social Utility of Entrepreneurial Lawyers, $155 \mathrm{U}$ Pa L Rev 103, 105 (2006); see also Brian Fitzpatrick, Do Class Action Lawyers Make Too Little? 158 U Pa L Rev 2043 (2010) (suggesting that the deterrence value of class actions justifies higher fees for lawyers, especially when the class benefits little). The problem with this argument is the same one that underlies the Ninth Circuit's misapplication of Discover Bank: it assumes, controversially, that the measure of the validity of a procedural rule is its deterrence value. See Stephen B. Burbank, Aggregation on the Couch: The Strategic Uses of Ambiguity and Hypocrisy, 106 Colum L Rev 1924, 1929 (2006) ("where is the authority to promulgate a rule with the purpose ... of enabling vigorous enforcement ... ?"); Beisner, Shors, and Miller, 57 Stan L Rev at 1442 (cited in note 68) ("if the true purpose of the 
fendant to wish to avoid classwide actions-including class arbitration-in order to avoid the large additional expense of attorneys' fees. The ATTM contract, typical of third-generation clauses, thus attempted to provide sufficient incentive to attorneys (by paying twice their fees) even in the absence of the more substantial class-action payoff.

In summary, the ATTM clause was almost certainly not exculpatory, and therefore should not have been found unconscionable. By insisting that it was, the plaintiffs, the lower courts, and the dissenting Justices forced the majority to confront the preemption question. The result was a disastrously broad opinion that abrogated Discover Bank (and its equivalents) even for the second-generation clauses (and their equivalents). AT\&T Mobility may even be read by some courts to make harsh first-generation clauses enforceable, because the invalidity of such contracts rests on the same general doctrine of unconscionability that the Court found preempted by the FAA. The majority opinion thus serves as an invitation for corporations to go back to contracts of adhesion that are much less consumer friendly than the ATTM contract.

Was there any way to avoid this fiasco? If my analysis was correct, then there was a way at every stage in the litigation. The simplest solution, of course, would have been for the plaintiffs' lawyers to refrain from challenging ATTM's class waiver-focusing instead on more exculpatory contracts-or for the lower federal courts to have found the waiver valid. But even at the Supreme Court, the damage could have been minimized. The dissenting Justices should have conceded that the Ninth Circuit erred in its application of California law, ${ }^{69}$ rather than insisting that the clause was invalid. That would have set up a reversal on narrow grounds, and they might have attracted at least one more vote. We can't be sure, of course. But in other cases last Term, several Justices in the AT\&T Mobility majority refused to sign on to broad pro-

class concept were to facilitate private law enforcement" it would violate the Rules Enabling Act, which "authorizes the federal judicial branch to create nothing more than purely procedural mechanisms"). Even if we cannot sharply distinguish between substance and procedure, we should place some limits on the substantive effects of rules of procedure. See John Hart Ely, The Irrepressible Myth of Erie, 87 Harv L Rev 693 (1974). A full discussion is beyond the scope of this article, but wherever we draw the line, maximizing deterrence seems to be on the substantive side. In any event, in most class actions, the primary motivation of class counsel is to maximize fees, not achieve optimal deterrence. See Jay Tidmarsh, Rethinking Adequacy of Representation, 87 Tex L Rev 1137, 1170 (2009).

${ }^{69}$ See Salve Regina College v Russell, 499 US 225 (1991) (holding appellate courts should decide questions of state law de novo, with no deference to district court determination). 
nouncements, concurring only in the judgment because they preferred to rely on narrower grounds. ${ }^{70}$ Perhaps a similar approach would have been attractive in this case-and, if the dissenting Justices had been the ones proposing it, they would have put together a majority. In particular, Justice Thomas, who takes a very dim view of what he calls "purposes-and-objectives" preemption, ${ }^{71}$ might have joined an opinion reversing the Ninth Circuit without reaching the preemption question. It would then have been the Justices urging broad preemption who would have been reduced to writing nonprecedential concurrences.

The lawyers and judges who would settle for nothing short of the invalidation of all arbitration waivers ended up with a decision that arguably creates a regime prohibiting the invalidation of any. Through their obduracy, they squandered the opportunity to cabin the damage done by the majority's broad preemption holding. That was unconscionable.

\section{Wal-Mart v Dukes}

Wal-Mart differs from AT\&T Mobility in a number of ways, but it ultimately illustrates the same dangers of overreaching. The Court was again correct in rejecting certification of the Wal-Mart class, but this time the majority's reasoning was sound. In this section, therefore, I begin not by criticizing the majority's reasoning but by defending it, showing that the plaintiffs tried to stretch existing doctrine too far. However, the majority opinion contained some broad language and other potentially troublesome aspects that may bear harmful fruit in future cases. And the dissenting opinion, by highlighting some of that language, increases the probability that the case will be read broadly in the future. As in AT\&T Mobility, the plaintiffs and their sympathizers might have

\footnotetext{
${ }^{70}$ See, for example, 7. McIntyre Machinery, Ltd. v Nicastro, 131 S Ct 2780, 2793 (2011) (Breyer, J, joined by Alito, J, concurring in judgment) ("this [case] is an unsuitable vehicle for making broad pronouncements that refashion basic jurisdictional rules"); Ortiz v fordan, 131 S Ct 884, 893 (2011) (Thomas, J, joined by Scalia, J, and Kennedy, J, concurring in judgment) ("I would limit our decision to the question presented and remand for consideration of any additional issues.").

${ }^{71}$ See Wyeth, $129 \mathrm{~S} \mathrm{Ct}$ at 1205, 1211-18 (Thomas, J, concurring in judgment); see also AT\&T Mobility, $131 \mathrm{~S}$ Ct at 1754 (Thomas, J, concurring). See also Gregory M. Dickinson, An Empirical Study of Obstacle Preemption in the Supreme Court, 89 Neb L Rev 682 (2011) (documenting Justice Thomas's aversion to obstacle preemption).
} 
limited the damage done by the decision if they had not been greedy.

\section{A. REACHING TOO HIGH: UNCONSCIOUS DISCRIMINATION}

The Wal-Mart plaintiffs were more sympathetic, but the overreaching by lawyers and judges had similar consequences. The plaintiffs alleged that their employer, Wal-Mart, had violated Title VII by discriminating against them on the basis of their gender in salary and promotion decisions. Based on the affidavits submitted in the case, it seems very likely that some female employees were indeed discriminated against and could have prevailed in individual suits against the company.

The overreaching in the case started at its very inception: Rather than suing individually, Betty Dukes and several other Wal-Mart employees brought a nationwide class action on behalf of 1.5 million current and former female employees. They alleged that the company intentionally discriminated on the basis of gender. It did so, they argued, by granting complete discretion to individual store managers to make salary and promotion decisions and simultaneously creating a "corporate culture" of gender bias.

No class action of this magnitude had ever been certified. The class consisted of a million and a half members, working at 3,400 stores, alleging discrimination by what the Court characterized as "a kaleidoscope of supervisors (male and female), subject to a variety of regional policies that all differed." $" 72$

Rule 23(a)(2) requires at least one "question[] of law or fact common to the class" in order for certification to be appropriate. As both the majority and the dissent recognized, this requirement really focuses on the common resolution of questions:

What matters to class certification . . . is not the raising of common "questions"-even in droves-but, rather the capacity of a classwide proceeding to generate common answers apt to drive the resolution of the litigation. ${ }^{73}$

${ }^{72}$ Wal-Mart Stores, Inc. v Dukes, 131 S Ct 2541, 2557 (2011), quoting Dukes v Wal-Mart Stores, Inc., 603 F3d 571, 652 (9th Cir 2010) (Kozinski dissenting).

${ }^{73} 131 \mathrm{~S}$ Ct at 2551, quoting Richard Nagareda, Class Certification in the Age of Aggregate Proof, 84 NYU L Rev 97, 132 (2009) (emphasis in original). See also id at 2567 (Ginsburg, J, dissenting): "Thus, a 'question' 'common to the class' must be a dispute, either of fact or of law, the resolution of which will advance the determination of the class members' claims" (emphasis added). 
Because of the decentralized decision making by Wal-Mart managers, claims by members of the class would not share any common answers to the question "why was I disfavored?" 74 unless the plaintiffs could "provide a nexus between the subjective decision-making and discrimination." $" 75$

The plaintiffs argued that the required nexus was a companywide policy of discrimination. But Wal-Mart had an official policy against discrimination, imposed penalties for $\mathrm{EEO}$ violations, and had won national diversity awards. ${ }^{76}$ Plaintiffs therefore had to rely on a claim that despite Wal-Mart's announced anti-discrimination policies, a "corporate culture" of gender bias existed, providing the glue that linked the disparate individual claims together.

The most significant problem with the plaintiffs' theory is that there was insufficient evidence that such a corporate culture-if it existed-caused the discrimination against all, or even most, of the members of the class. Without a common cause for the individual discriminatory acts, the plaintiff class lacked a common question (or common answers). ${ }^{77}$ Plaintiffs attempted to show causation through the testimony of Dr. William Bielby, their sociological expert. Relying on the concept of "social frameworks," Dr. Bielby testified that Wal-Mart was "vulnerable" to gender bias ${ }^{78}$ and that gender stereotyping likely influenced many promotion and salary decisions made by individual Wal-Mart managers. ${ }^{79}$

But Dr. Bielby's testimony was insufficient to show causation, for two reasons. First, he conceded that gender stereotyping might

\footnotetext{
${ }^{74} 131 \mathrm{~S} \mathrm{Ct}$ at 2552.

${ }^{75}$ Dukes v Wal-Mart Stores, Inc., 222 FRD 137, 150 (ND Cal 2004), aff'd in part and rem'd in part, 603 F3d 571 (9th Cir 2010), rev'd Wal-Mart Stores Inc. v Dukes, $131 \mathrm{~S} \mathrm{Ct}$ 2541 (2011).

${ }^{76}$ See Wal-Mart, $131 \mathrm{~S} \mathrm{Ct}$ at 2553 (policy, penalties); Dukes, 222 FRD at 154 (penalties, awards).

${ }^{77}$ Note that requiring plaintiffs to show causation is not equivalent to requiring them to prove their case on the merits. To obtain class certification, plaintiffs must "affirmatively demonstrate" compliance with Rule 23's requirements, Wal-Mart, $131 \mathrm{~S}$ Ct at 2551, including the existence of a common question. Plaintiffs were relying on the theory of corporate culture to weave together the individual acts of discrimination into a single classwide common question. At the certification stage, then, they did not need to prove the existence of the corporate culture, but they did need to prove that the individual acts alleged to be discriminatory arose from some common source, whether corporate culture or something else. In other words, they had to show that corporate culture really was the causative glue.
}

\footnotetext{
${ }^{78}$ Dukes, $222 \mathrm{FRD}$ at 154.

${ }^{79}$ Id at 153 .
} 
have influenced as few as half a percent of employment decisions at Wal-Mart. ${ }^{80}$ The possibility that corporate culture motivated such a small number of decisions deprived that culture of its status as the link among the disparate individual acts of discrimination; Dr. Bielby's testimony therefore could not establish the existence of a common question.

Dr. Bielby also misused the concept of social frameworks by using general research findings to draw conclusions about a specific case. ${ }^{81}$ As described by one group of prominent social-framework scholars, Dr. Bielby "utilized no standardized cultural assessment tool, no employee surveys or interviews, nor any causal testing" to conclude that "gender was a causal factor in some unspecified percentage of all personnel decisions at all Wal-Mart facilities across the USA." 82 Because his testimony was based on general research rather than on an examination of Wal-Mart or its employees, it could not demonstrate a causal link between corporate culture and any individual employment decision. Such a link cannot be assumed: There is research suggesting that implicit bias (in other words, individual internalization of a discriminatory corporate culture) does not predict discriminatory behavior. ${ }^{83}$

Once we strip away Dr. Bielby's testimony, the Wal-Mart plaintiffs are left with anecdotal evidence of individual instances of discrimination, and statistics that arguably demonstrate that women were paid less and promoted less frequently than men. Neither suffices to demonstrate the "common question" required for class certification.

As the majority noted, the anecdotal evidence was "too weak to raise any inference that all the individual, discretionary personnel

\footnotetext{
${ }^{80}$ Dukes v Wal-Mart, 222 FRD 189, 192 (ND Cal 2004) (ruling on motion to strike expert testimony).

${ }^{81}$ See John Monahan, Laurens Walker, and Gregory Mitchell, Contextual Evidence of Gender Discrimination: The Ascendance of "Social Frameworks," 94 Va L Rev 1715 (2008). This essay, two of whose authors were the only sources relied on by Bielby in his analysis, specifically criticizes his testimony in this case. See id at 1716. The same authors in a later article assert that "expert opinions" that rely on "general scientific evidence to make case-specific descriptive and causal claims . . . lack legal or scientific justifications." John Monahan, Laurens Walker, and Gregory Mitchell, The Limits of Social Framework Evidence, 8 L Prob \& Risk 307, 309 (2009).

${ }^{82}$ Monahan, Walker, and Mitchell, $8 \mathrm{~L}$ Prob \& Risk at 312 (cited in note 81).

${ }^{83}$ See Gregory Mitchell and Philip E. Tetlock, Antidiscrimination Law and the Perils of Mindreading, 67 Ohio St L J 1023, 1033-34, 1065-72; Amy L. Wax, The Discriminating Mind: Define It, Prove It, 40 Conn L Rev 979, 984-85 (2008); Amy Wax, Discrimination as Accident, 74 Ind L J 1129, 1139-42 (1999).
} 
decisions are discriminatory." ${ }^{4}$ The dissent's contrary view of the anecdotal evidence suffered from one of the same problems that plagued Dr. Bielby's testimony. The dissenting Justices asserted that the anecdotal evidence "suggest[ed] that gender bias suffused Wal-Mart's company culture." ${ }^{85}$ But even if that is true, there was no evidence that a discriminatory culture caused all—or even any-of the allegedly discriminatory employment decisions. The whole notion of a discriminatory company culture depends on an unjustified assumption that anyone immersed in a particular cultural milieu will necessarily respond to it in the same discriminatory manner. Without that unjustified assumption, there is no question common to all class members: Each class member is alleging an individual act of discrimination that might have occurred with or without a biased corporate culture.

Plaintiffs also introduced statistical evidence in the form of regression analyses. Holding other variables constant, plaintiffs' expert found statistically significant differences between men and women in both salary and promotion levels. ${ }^{86}$ If there were nothing else to explain those differences, it might be plausible to conclude that company-wide gender discrimination caused them. ${ }^{87}$ But there was something else, something much more likely than intentional discrimination by Wal-Mart. The disparities at Wal-Mart closely mirrored nationwide salary and promotion disparities. ${ }^{88}$ As one commentator put it:

One might say that if Wal-Mart were indeed discriminating . . . then its execution of that enterprise was startlingly inept. If a highly organized, national employer really intended to keep down its female hourly

${ }^{84} 131 \mathrm{~S}$ Ct at 2556.

${ }^{85} \mathrm{Id}$ at 2563 (Ginsburg, J, dissenting). The dissent also accused the majority of requiring a specified number of anecdotes. Id at $2564 \mathrm{n} 4$. To be fair, while the majority mentions the lack of a causal link, it focuses on the number of anecdotes and also asserts that "a few anecdotes selected from literally millions of employment decisions prove nothing at all." $131 \mathrm{~S} \mathrm{Ct}$ at 2556 \& n 9.

${ }^{86}$ See id at 2555; see also id at 2564 (Ginsburg, J, dissenting).

${ }^{87}$ There are still some problems with that conclusion. The majority and the dissent disagreed about whether the statistical analyses demonstrated disparities within stores. See $131 \mathrm{~S} \mathrm{Ct}$ at 2555 (majority); id at $2564 \mathrm{n} 5$ (dissent) (labeling it an "arcane disagreement about statistical method"). More fundamentally, regression analysis is a flawed techniquedespite its almost universal judicial acceptance-for demonstrating intentional discrimination, because it shows only a correlation between a chosen set of variables rather than whether changes in one variable cause changes in the other. See D. James Greiner, Causal Inference in Civil Rights Litigation, 122 Harv L Rev 534 (2008).

${ }^{88}$ See Nagareda, 84 NYU L Rev at $154-55$ (cited in note 73 ). 
employees, then one would think that it could manage to become more than just a "conduit" for broader labor-market characteristics. ${ }^{89}$

The statistical evidence shows only that Wal-Mart behaved no differently than most American employers. There was no showing that the disparities were caused by a unique corporate culture at Wal-Mart rather than by whatever caused the broad labor-market disparities in general. Again, this is not to say that Wal-Mart supervisors did not discriminate, but only that the statistical evidence is not enough to demonstrate the company-wide policy of discrimination that is the necessary predicate for the court to find a common question.

It is important to remember that, as in AT\&T Mobility, the plaintiffs in Wal-Mart had an economically and legally viable alternative to a class action suit. With strong evidence that individuals were the victims of intentional discrimination, significant back-pay awards at stake, and attorneys' fees available in all except frivolous cases, individual suits under Title VII were marketable. Some plaintiffs might also have been able to bring smaller class actions focused on particular regions or particular employment opportunities. ${ }^{90}$ Instead, they tried to combine all possible claims into a single class action.

Why might they have taken that risky approach? I suggest that just as the insistence on unconscionability in AT\&T Mobility rested (at least in part) on a desire to insert deterrence concerns into Rule 23, the seemingly incomprehensible decision to proceed as a class action in Wal-Mart can be explained as a desire to change the substantive law of employment discrimination. The allegation of a culture of discrimination was essentially an attempt to write into Title VII the concepts of structural discrimination and implicit bias. ${ }^{91}$ Some scholars have been urging this approach for over two decades, beginning with Charles Lawrence's seminal article in $1987 .^{92}$ These scholars argue that even as overt, conscious

\footnotetext{
${ }^{89}$ Id at 155.

${ }^{90}$ Indeed, plaintiffs' attorneys recently filed a much smaller class action in California federal court on behalf of about 90,000 women in four regions in California and neighboring states. See Andrew Martin, Female Wal-Mart Employees File New Bias Case, New York Times (Oct 27, 2011), available at http://www.nytimes.com/2011/10/28/business/ women-file-new-class-action-bias-case-against-wal-mart.html scp $=1 \& s q=\& s t=$ nyt .

${ }^{91}$ See Nagareda, 84 NYU L Rev at 152-62 (cited in note 73).

${ }^{92}$ Charles R. Lawrence III, The Id, the Ego, and Equal Protection: Reckoning with Unconscious Racism, 39 Stan L Rev 317 (1987).
} 
discrimination is fading, implicit bias continues unabated. Unconscious discrimination is so pervasive that it is woven into the structure of institutions, the theory goes, and if we do not restructure discrimination law to make it legally actionable we will make no progress against the persistence of discrimination. ${ }^{93}$ One commentator describes this scholarship in language that almost mirrors the Wal-Mart plaintiffs' claims: Disparities in wages and promotions continue to exist "because workplace structures facilitate conduct-often driven by subtle or unconscious bias- that operates as a drag on the achievements" of women and minorities. $^{94}$

But such a theory distorts Title VII beyond recognition. It is one thing to allege that a particular individual has unconsciously discriminated (that is, that he has acted out of an unrecognized prejudice), but quite another to argue-as the Wal-Mart plaintiffs' theory does-that the entire workplace culture is infected with unrecognized bias. Such an argument moves Title VII from a prohibition against intentional discrimination to a prohibition against a workforce that does not "look like America." 95

The idea of implicit bias has remained controversial within the academy and has never made any headway outside it. Indeed, there is no credible scientific evidence to support the existence of the alleged widespread unconscious discrimination that purportedly

\footnotetext{
${ }^{93}$ See, for example, Virginia Valian, Why So Slow? The Advancement of Women (MIT, 1998); Patrick S. Shin, Liability for Unconscious Discrimination? A Thought Experiment in the Theory of Employment Discrimination Law, 62 Hastings L J 67 (2010); Ivan E. Bodensteiner, The Implications of Psychological Research Related to Unconscious Discrimination and Implicit Bias in Proving Intentional Discrimination, 73 Mo L Rev 83 (2008); Tristin K. Green, A Structural Approach as Antidiscrimination Mandate: Locating Employer Wrong, 60 Vand L Rev 849 (2007); Audrey J. Lee, Note, Unconscious Bias Theory in Employment Discrimination Litigation, 40 Harv CR-CL L Rev 481 (2005); Susan Sturm, Second Generation Employment Discrimination: A Structural Approach, 101 Colum L Rev 458 (2001); Linda Hamilton Krieger, The Content of Our Categories: A Cognitive Bias Approach to Discrimination and Equal Employment Opportunity, 47 Stan L Rev 1161 (1995).

${ }^{94}$ Samuel R. Bagenstos, The Structural Turn and the Limits of Antidiscrimination Law, 94 Cal L Rev 1, 2 (2006). Compare this to the "basic theory" of the plaintiffs' case in WalMart: "a strong and uniform 'corporate culture' permits bias against women to infect, perhaps subconsciously, the discretionary decisionmaking of each one of Wal-Mart's thousands of managers." $131 \mathrm{~S} \mathrm{Ct}$ at 2548.

${ }^{95}$ Even scholars who support the concept of structural discrimination find it inconsistent with current law. Professor Samuel Bagenstos, who believes that there is implicit bias and "find[s] the case for a structural approach to employment discrimination law . . . compelling" nevertheless recognizes that remedying the structural inequalities that result from implicit bias is inconsistent with "the generally accepted normative underpinnings of antidiscrimination law." Bagenstos, 94 Cal L Rev at 3 (cited in note 94); see also Wax, 74 Ind $\mathrm{L} \mathrm{J}$ at 1146-52 (cited in note 83).
} 
results in structural discrimination. ${ }^{96}$ The Wal-Mart class action can nevertheless be seen as an attempt to turn implicit bias theory into explicit law. Bringing a class action in order to rewrite the substantive law of employment discrimination to include implicit bias and structural discrimination was thus overreaching at its worst.

\section{B. THE HARM OF OVERREACHING AND OVERWRITING}

As in AT\&T Mobility, the strategy backfired. Overreaching by the plaintiffs and the dissenters led to a majority opinion that was broader and more harmful than a simple rejection of class certification would have been. Had the majority crafted a narrower opinion, the repercussions for future class actions would have been less significant. In short, if a lower court or a unanimous Supreme Court had held that class certification was inappropriate under Rule 23(a), ${ }^{97}$ the accompanying opinion might have been quite different. Four aspects of the majority opinion are particularly noteworthy.

First, the majority opinion can be interpreted as ratcheting up the requirements for class certification. The Wal-Mart suit was brought under Rule 23(b)(2), which meant that it-like all class actions - had to satisfy the requirements of Rule 23(a), but not the more demanding requirements of Rule 23(b)(3). While Rule 23(a)(2) requires only a single common question, Rule 23(b)(3) requires that the common questions predominate over individual ones. The dissent accused the majority of conflating the commonality requirement of Rule 23(a)(2) with the predominance requirement of Rule 23(b)(3). ${ }^{98}$ By blending the two, the dissent charged, the majority "elevate[d] the (a)(2) inquiry so that it is no longer "easily satisfied." 99

\footnotetext{
${ }^{96}$ For a thorough discrediting of the purported "evidence" for the pervasiveness of unconscious discrimination, see Mitchell and Tetlock, 67 Ohio St L J (cited in note 83); Hal R. Arkes and Philip E. Tetlock, Attributions of Implicit Prejudice, or "Would Fesse Fackson 'Fail' the Implicit Association Test?" 15 Psychol Inquiry 257 (2004).

${ }^{97}$ In Wal-Mart, the majority and the dissent agreed that the class was improperly certified under Rule 23(b)(2) for reasons irrelevant to my arguments. See 131 S Ct at 2557-61 (majority); id at 2561-62 (dissent). They disagreed over whether the suit met the commonality requirements of Rule 23(a).

${ }^{98} \mathrm{Id}$ at 2561-62, 2565-66 (Ginsburg, J, dissenting).

${ }^{99}$ Id at 2565 (Ginsburg, J, dissenting), quoting John W. Moore, et al, 5 Moore's Federal Practice $\$ 23.23[2]$ at 23-72 (Matthew Bender, 3d ed 2011).
} 
The dissenters were both right and wrong. They were wrong in contending that the majority conflated the requirements of 23(a)(2) and 23(b)(3) — as the majority concluded, there was simply not enough evidence of even a single common question. But the intuition that the majority might be performing some kind of alchemy on the 23(a)(2) commonality requirement, "elevat[ing]" it beyond previous incarnations, is supported by language in the majority opinion. Most troubling is the majority's assertion that the plaintiffs failed to establish the existence of a common question because they provided "no convincing proof" of a company-wide discriminatory policy. ${ }^{100}$ Similarly, the majority rejected the statistical evidence as "insufficient to establish that respondents' theory can be proved on a classwide basis." ${ }^{101}$ These statements might be read to suggest that plaintiffs seeking class certification must come very close to proving their case on the merits. ${ }^{102}$

The majority rightly asserted that the precedents require a "rigorous analysis" to determine whether a plaintiff seeking class certification has demonstrated actual compliance with the requirements of Rule $23 .{ }^{103}$ As the majority also noted, "[f]requently, that 'rigorous analysis' will entail some overlap with the merits of the plaintiff's underlying claim." ${ }^{104}$ But there is a line, however fine, between that "rigorous analysis" and actual proof of the merits of the case. The language about "convincing proof" creates some ambiguity about where that line lies. Lower courts-or the Supreme Court in a future case-might use the language to impose a higher burden and deny certification even in cases with stronger

${ }^{100} 131 \mathrm{~S} \mathrm{Ct}$ at 2556 (emphasis added).

${ }^{101}$ Id at 2555 (emphasis added).

${ }^{102}$ Lower courts had already recognized-and the Court in Wal-Mart confirmed-that a plaintiff seeking certification must demonstrate satisfaction of the relevant Rule 23 requirements, even if that necessitates some review of the merits. See, for example, In re: Hydrogen Peroxide Antitrust Litigation, 552 F3d 305 (3d Cir 2008); In re Initial Public Offerings Securities Litigation, 471 F3d 24 (2d Cir 2006). But the Court's language in WalMart seems to raise the standard even higher.

${ }^{103} 131 \mathrm{~S}$ Ct at 2551. The dissent does not appear to disagree.

${ }^{104}$ Id. Again, the dissent makes no comment. Despite some confounding language in Eisen $v$ Carlisle and Jacquelin, 417 US 156, 177 (1974), which the Wal-Mart Court labeled as "the purest dictum," $131 \mathrm{~S} \mathrm{Ct}$ at $2552 \mathrm{n} \mathrm{6}$, lower courts had already reached this conclusion. See Wal-Mart, 603 F3d at 581-86; Hydrogen Peroxide, 552 F3d at 309; Oscar Private Equity Investments v Allegiance Telecom, Inc., 487 F3d 261, 268 (5th Cir 2007); In re Initial Public Offerings Securities Litigation, 471 F3d 24, 33 (2d Cir 2006); Gariety v Grant Thornton, LLP, 368 F3d 356, 366 (4th Cir 2004); Szabo v Bridgeport Machines, Inc., 249 F3d 672, 676 (7th Cir 2001). 
evidence than the Wal-Mart plaintiffs provided. The dissent's claim that the majority elevated the burden might become a selffulfilling prophecy, even though the dissent misidentified the source of the problem.

The second troubling aspect of the majority opinion is its treatment of the anecdotal evidence. As I noted earlier, the majority found the anecdotal evidence too weak to create a causal inference. But in support of that conclusion, the majority focused not on the absence of any linkage between the allegedly discriminatory culture and the individual employment decisions, but instead on the small number of anecdotes and the fact that they were from stores in a small number of states. ${ }^{105}$ Again, then, the dissenters had some justification for their accusation that the majority created a "numerical floor before anecdotal evidence can be taken into account."106 And both the majority's focus on the number of anecdotes and the dissent's accusation might lead to later decisions citing Wal-Mart for the proposition that there is a numerical floor.

Two final issues arise in Part III of the majority opinion, in which all nine Justices joined and which concluded that this particular lawsuit should not have been certified under Rule 23(b)(2). Here, too, the analysis is broader than it needs to be, again suggesting that the plaintiffs' overreaching produced disastrous results.

The Court first suggested that the "procedural protections" of Rule 23(b)(3) - including the right to opt out-are constitutionally required by the Due Process Clause under Phillips Petroleum Co. $v$ Shutts,${ }^{107}$ at least in suits predominantly seeking damages. ${ }^{108}$ But that is not the holding of Shutts, which involved complicated personal-jurisdiction issues intertwined with the class certification question. As a number of commentators have noted, reading the opt-out provision as constitutionally required is an "extreme reading" of Shutts. ${ }^{109}$ In reading Shutts to constitutionalize the opt-out

\footnotetext{
105 See text accompanying notes $84-85$.

${ }^{106} 131 \mathrm{~S} \mathrm{Ct}$ at $2563 \mathrm{n} 4$ (Ginsburg, J, dissenting).

107472 US 797 (1985).

${ }^{108}$ See $131 \mathrm{~S} \mathrm{Ct}$ at 2559: "In the context of a class action predominantly for money damages we have held that absence of notice and opt-out violates due process. See [Shutts]."

${ }^{109}$ Diane P. Wood, Adjudicatory Furisdiction and Class Actions, 62 Ind L J 597, 605-06 (1987). See also Redish, Wholesale fustice at 158 (cited in note 68); Tobias Barrington Wolff, Federal Furisdiction and Due Process in the Era of the Nationwide Class Action, $156 \mathrm{U}$ Pa L Rev 2035, 2076-109 (2008); David L. Shapiro, Class Actions: The Class as Party and
} 
requirement, the Wal-Mart Court elided the difference between constitutional requirements and those derived from rules or statutes, a form of "intellectual slippage" that narrows the authority of the legislature. ${ }^{110}$ Should Congress at some time in the future wish to expand the reach of mandatory class actions, Wal-Mart's interpretation of Shutts will stand in the way.

Finally, in addressing the inappropriateness of certification under Rule 23(b)(2), the Court considered the Ninth Circuit's solution to the problem that Wal-Mart might have individual defenses to claims by some class members. Even if plaintiffs could establish a pattern or practice of discrimination, the Court noted, not every class member would be entitled to damages-Wal-Mart might be able to "show that it took an adverse employment action against an employee for [a] reason other than discrimination." 111 The Court of Appeals, recognizing this possibility, suggested that the district court could allow Wal-Mart "to present individual defenses in . . . randomly selected 'sample cases,' thus revealing the approximate percentage of class members whose unequal pay or nonpromotion was due to something other than gender discrimination." 112 The court could then "extrapolat[e] the validity and value of the untested claims from the sample set."113

In one short paragraph, the Supreme Court "disapprove[d] that novel project," calling it "Trial by Formula." ${ }^{114}$ But such statistical sampling is not as novel as the Court would have it, nor is it necessarily inappropriate. Statistical sampling of various sorts, including both survey evidence and bellwether trials, has been used

Client, 73 Notre Dame L Rev 913, 954-55 (1998); Arthur R. Miller and David J. Crump, Furisdiction and Choice of Law in Multistate Class Actions After Phillips Petroleum Co. v. Shutts, 96 Yale L J 1, 31-32 (1986). Cf. Henry Paul Monaghan, Antisuit Injunctions and Preclusion Against Absent Nonresident Class Members, 98 Colum L Rev 1148, 1166 (1998) ("Shutts is about due process limitations on state court in personam jurisdiction over absent, nonresident class 'plaintiffs"') (emphasis added); Patrick Woolley, Collateral Attack and the Role of Adequate Representation in Class Suits for Money Damages, 58 U Kan L Rev 918, 971-75 (2010) (agreeing with Monaghan).

${ }^{110}$ The notion of "intellectual slippage" of this sort was first suggested in David E. Engdahl, The Classic Rule of Faith and Credit, 118 Yale L J 1584, 1589 (2009).

${ }^{111} 131 \mathrm{~S}$ Ct at 2560-61. It is ironic that the dissenting Justices joined this portion of the opinion. By suggesting that not every pay or promotion decision was tainted by discrimination, the Court is essentially reiterating that plaintiffs have shown an insufficient causal link between a hypothetical company-wide policy and the harms to class members.

${ }_{112} 603 \mathrm{~F} 3 \mathrm{~d}$ at $627 \mathrm{n} 56$, quoted in $131 \mathrm{~S} \mathrm{Ct}$ at 2550.

${ }^{113} 131 \mathrm{~S} \mathrm{Ct} 2550$.

${ }^{114} \mathrm{Id}$ at 2561. 
in a few legal contexts. ${ }^{115}$ A number of commentators have explained its value (in allowing the accurate resolution of cases that could not otherwise be resolved because of scarcity of judicial resources) and demonstrated how it can be consistent with the Constitution and with our litigation regime. ${ }^{116}$ Indeed, to the extent that statistical sampling is problematic at all, it is problematic for plaintiffs: While it produces an amount of damages that is accurate overall, it may distribute those damages in a less than perfect fashion. ${ }^{117}$ No commentator has suggested that defendants have any ground to object to sampling. In addition, the question of the validity of statistical sampling as a technique for resolving large-scale disputes necessarily prompts a comparison to other techniques; at least in some contexts, empirical research has shown that traditional trials often do not provide the benefits thought to flow from individualized adjudication. ${ }^{118}$ In a world of increasingly globalized harm and limited judicial resources, sampling might ultimately serve the interests of both plaintiffs and defendants.

The Court considered none of this information in concluding that statistical sampling violated the Rules Enabling Act. Nor did it consider whether such a ruling might be premature. The use of statistical sampling in the context of class actions is still in its infancy. In the scientific context, it took decades for statistical

${ }^{115}$ See In re Estate of Marcos Human Rights Litigation, 910 F Supp 1460 (D Hawaii 1995), aff'd, Hilao v Estate of Marcos, 103 F3d 767 (9th Cir 1996); Cimino v Raymark Industries, Inc., 751 F Supp 649 (ED Tex 1990), rev'd, 151 F3d 297 (5th Cir 1998). See also Laurens Walker and John Monahan, Sampling Damages, 83 Iowa L Rev 545, 559-60 (1998) (documenting uncontroversial use of surveys-a form of sampling-in trademark cases since 1963).

${ }^{116}$ See, for example, Alexandra D. Lahav, The Case for "Trial by Formula," 90 Tex L Rev (forthcoming 2012), available at http://ssrn.com/abstract=1945514; Alexandra D. Lahav, Bellwether Trials, 76 Geo Wash L Rev 576 (2008); Laurens Walker and John Monahan, Sampling Evidence at the Crossroads, 80 S Cal L Rev 969 (2007); Laurens Walker and John Monahan, Sampling Liability, 85 Va L Rev 329 (1999); Walker and Monahan, 83 Iowa L Rev 545 (cited in note 115); Michael J. Saks and Peter David Blanck, Fustice Improved: The Unrecognized Benefits of Aggregation and Sampling in the Trial of Mass Torts, 44 Stan L Rev 815 (1992); Christopher J. Roche, Note, A Litigation Association Model to Aggregate Mass Tort Claims for Adjudication, 91 Va L Rev 1463 (2005). The dispute about statistical sampling and bellwether trials may be viewed as one facet of the larger argument between those who insist on individual autonomy and those who favor collective justice. See generally David Shapiro, Class Actions: The Class as Party and Client, 73 Notre Dame L Rev 913 (1998). The authorities cited in this note argue, however, that statistical sampling also serves the interests of individual plaintiffs.

${ }^{117}$ See Robert G. Bone, Statistical Adjudication: Rights, fustice, and Utility in a World of Process Scarcity, 46 Vand L Rev 561, 572-73 (1993).

${ }^{118}$ See Deborah Hensler, Resolving Mass Toxic Torts: Myths and Realities, 1989 U Ill L Rev 89 (1989). 
sampling to move from "early controversy" to "decisive acceptance." ${ }^{119} \mathrm{Had}$ statistical sampling in the law survived beyond WalMart, it might have proven similarly enduring-but the majority's "disapproval" ensured that we will never know.

Wal-Mart and AT\&T Mobility are thus similar in that the majority opinions may well have detrimental effects in the future. They differ, however, in the extent to which different choices by the dissent might have changed the jurisprudential landscape. Of course, in both cases the majority opinion would not have been written had the plaintiffs' lawyers not brought the class action in the first place, or had the lower courts rejected the plaintiffs' arguments. In AT\&T Mobility, it also seems quite likely that if the dissenting Justices had urged reversal on the ground that the Ninth Circuit misapplied California law, that view would have attracted a majority and the Court—or at least the majority opinion—would never have reached the preemption question.

As to Wal-Mart, however, my argument is that the dissenting Justices should have agreed with the majority's reasoning. How might that have cabined the troubling aspects of the majority opinion? For the two final issues, which arose in the context of the Rule 23(b)(2) requirements, the answer is straightforward. A court should first determine that the general requirements of Rule 23(a) are met, before moving on to the more specific requirements of the various subsections of Rule 23(b). The discussion of 23(b)(2) was therefore technically unnecessary, but in the circumstances of the actual case it was hard to avoid because the failure to satisfy (b)(2) was the reason that the dissenting Justices concurred in the judgment. Had the dissenting Justices instead agreed that the lower court should be reversed because of the lack of the common question required by Rule 23(a)(2), the Court would have been much less likely to go out of its way to reach the (b)(2) issue. In particular, as I noted with regard to AT\&T Mobility, some of the Justices in the majority are inclined to rule narrowly. ${ }^{120}$ While Justice Scalia might have convinced them that addressing the (b)(2) question was appropriate given actual Justices' votes, it seems likely that if there had been unanimity with regard to Rule 23(a), some-

\footnotetext{
${ }^{119}$ Walker and Monahan, $80 \mathrm{~S}$ Cal L Rev at 971 (cited in note 116).

${ }^{120}$ See note 70.
} 
one would have raised the question of whether it was appropriate to go beyond that issue.

For the troublesome language regarding "proof" and the creation of ambiguity regarding a numerical floor for anecdotes, I suggest that had the dissenting Justices not been so eager to discredit the majority's reasoning, they might have been better able to focus on the particular language. And that focus might have produced either of two results. First, Justice Scalia, as author of the opinion, might have been willing to tweak the language of the opinion at the request of Justices joining it, especially if doing so would allow the Court to issue a unanimous or nearly unanimous opinion. ${ }^{121}$ Second, even had the language remained in the opinion, the Justices who objected to it could have written a concurring opinion stressing the narrowness of the majority's holding instead of a dissenting opinion highlighting its potential breadth. Later interpreters-including both lower court judges and the Court itself in subsequent cases-looking for help in parsing the majority's language would be led to interpret it narrowly rather than broadly.

Language matters. There is a danger that future cases building on the Wal-Mart precedent will engage in the same kind of expansive interpretation as occurred between Bell Atlantic Corp. $v$ Twombly ${ }^{122}$ and Ashcroft $v$ Iqbal. ${ }^{123}$ The "plausibility" language of Twombly ${ }^{124}$-arguably appropriate in the circumstances of that case, but not well thought out-took on a life of its own in Iqbal. Dismissing the complaint in Twombly could be justified on the ground that an inference that defendants had acted unlawfully was not only not "plausible," but decidedly implausible. ${ }^{125}$ But in Iqbal,

${ }^{121}$ The Court benefits from-and therefore is likely to try to achieve-unanimity or near-unanimity, especially in controversial cases. See, for example, Howard Gillman, The Court as an Idea, Not a Building (or a Game): Interpretive Institutionalism and the Analysis of Supreme Court Decision-Making, in Cornell W. Clayton and Howard Gillman, eds, Supreme Court Decision-Making: New Institutionalist Approaches 65, 81 (Chicago 1999); Frank H. Easterbrook, Ways of Criticizing the Court, 95 Harv L Rev 802, 804 (1982); Kent Greenawalt, The Enduring Significance of Neutral Principles, 78 Colum L Rev 982, 1007 (1978).

122550 US 544 (2007).

${ }^{123} 129$ S Ct 1937 (2009).

${ }^{124}$ In Twombly, the majority opinion used "plausible," "plausibly," or "plausibility" sixteen times to describe the standard for withstanding a motion to dismiss. See 550 US at 556 \& n 4, 557 \& n 5, 558, 559, 560, 564, 566, 569 \& n 14, 570.

${ }^{125}$ See Suzanna Sherry, Foundational Facts and Doctrinal Change, 2011 Ill L Rev 145, 176 (2011); Robert G. Bone, Twombly, Pleading Rules, and the Regulation of Court Access, 94 Iowa L Rev 873, 900-09 (2009); Richard A. Epstein, Bell Atlantic v Twombly: How 
the Court moved from requiring plaintiffs to show that an inference of illegality is not implausible to requiring them to show that an inference of illegality is more likely than not. It seems clear from the fact that Justice Souter, the author of Twombly, was in dissent in Iqbal that this was not what (at least some members) of the Court meant by invoking a plausibility standard. But "more likely than not" is one reasonable interpretation of "plausible." 126 Had Justice Souter chosen his language more carefully in Twombly, the Court might have had a more difficult time concluding that Iqbal's complaint should have been dismissed.

The majority's language in Wal-Mart has the potential to work the same mischief. As in Twombly, the application of that language to the facts of the particular case is not problematic. But there is a danger that the language of "convincing proof" and "a few anecdotes selected from literally millions" might preclude certification in a case in which there is some (but not "convincing") evidence of a common question or a few more anecdotes. Such a consequence-potentially avoidable had the dissenting Justices agreed with the majority, focused on the language, and either exerted pressure to change it or written a concurrence minimizing its significance-is made even more likely by the fact that the dissent characterized it as making certification harder to obtain.

As in AT\&T Mobility, then, the lawyers and judges who wanted to have it all ended up with nothing. And in the process, they opened the door to a potential contraction of liability in future cases.

\section{The Need for Judicial Vigilance}

Two dangers inhere in Rule 23, one recognized and one hidden. The recognized danger is that plaintiffs' counsel-especially in class actions and other aggregated cases-often have both the opportunity and the incentive to favor their own interests at the expense of their clients' interests; various scholars have identified that danger and proposed solutions. ${ }^{127}$

Motions to Dismiss Become (Disguised) Summary fudgments, 25 Wash U J L \& Pol 61, 8490 (2007).

${ }^{126}$ One definition of "plausible" is: "Of an argument, an idea, a statement, etc.: seeming reasonable, probable, or truthful; convincing, believable." Oxford English Dictionary, online at http://www.oed.com/view/Entry/145466? redirectedFrom = plausible\#eid (definition 4a).

${ }^{127}$ See, for example, Tidmarsh, 87 Tex L Rev 1137 (2009) (cited in note 68); Howard 
But as Wal-Mart and AT\&T Mobility illustrate, the problem goes much deeper than the relationship between lawyers and clients. The further danger hidden in Rule 23 is that in class actions, much more than in individual cases, the ability of plaintiffs' counsel to frame the legal issues puts tremendous power into the hands of private attorneys general who owe no duty to the general public or to subsequent plaintiffs. Class actions, both because of their scope and because they are so often high profile, offer repeatplayer plaintiffs' lawyers a tempting opportunity to try to shape the law rather than simply to win a judgment. If class-action lawyers cannot always be counted on to put their own clients' interests first, how can we expect them to worry about the interests of those who are not even clients? Lawyers in this situation thus have an enormous incentive to overframe (and overargue) the legal issues and go for the big win-for both themselves and their existing clients. Ultimately, though, when the hogs get slaughtered, it is future plaintiffs who pay the price. The biggest losers in AT\&T Mobility and Wal-Mart were not the class members, who deserved to lose on their particular claims, but consumers and employees who might wish to bring class actions in the future.

The real tragedy of AT\&T Mobility and Wal-Mart is not that the plaintiffs' lawyers overreached, it is that the Ninth Circuit and the dissenting Justices took the bait and bought into the overframing of the issues. Had they been more focused on the narrow procedural questions and less dazzled by the lawyers' grandiose claims, they might have reached different conclusions.

These two cases also suggest a solution to this inherent danger of Rule 23, one that does not require rewriting the rule or tinkering with doctrine. Instead, judges need only be alert to the danger and take steps to avert it. ${ }^{128}$ The courts should serve as a safeguard against lawyers' short-sighted strategic decisions, not act in complicity with them. Just as courts are vigilant in moni-

M. Erichson and Benjamin C. Zipursky, Consent versus Closure, 96 Cornell L Rev 265 (2011). The core problem is that the development of an entrepreneurial plaintiffs' bar ends up replicating, as between lawyer and client (or potential client), the conflicts between repeat-player "haves" and one-shot "have-nots" that Professor Marc Galanter identified a generation ago. Marc Galanter, Why the "Haves" Come Out Ahead: Speculations on the Limits of Legal Change, 9 L \& Soc Rev 95 (1974). On the replication at the lawyer-client level, see John Fabian Witt, Bureaucratic Legalism, American Style: Private Bureaucratic Legalism and the Governance of the Tort System, 56 DePaul L Rev 261 (2007).

${ }^{128}$ It would help if Supreme Court Justices-and court of appeals judges-had more litigation experience as lawyers or trial judges. See Suzanna Sherry, Logic Without Experience: The Problem of Federal Appellate Courts, 82 Notre Dame L Rev 97 (2006). 
toring legislative or administrative aggrandizement, they should protect the system as a whole from overreaching by lawyers whose loyalties lie elsewhere.

\section{Conclusion}

More than a decade ago, Professor William Rubenstein warned of the potential conflicts arising out of simultaneous civil rights litigation by "professional public interest litigators" and "occasional pro bono attorneys." ${ }^{29}$ The problem is that the latter-unaware of or indifferent to the big picture-might bring weak or badly timed cases that establish bad precedent for other similarly situated litigants. In ATむT Mobility and Wal-Mart, we see this scenario writ large. Rather than a conflict between two sets of litigators, it is a conflict between a powerful plaintiffs' bar and the mass of ordinary consumers and employees.

But the real culprits in these cases were the lower court judges and dissenting Justices. In a context in which both parties had incentives to distort the issues, these judges abdicated their responsibility to frame the issues objectively. Accepting the plaintiffs' claims at face value, they backed a player who was overplaying his hand-and consequently failed to notice the powerhouse across the table. Faced with weak arguments in novel cases with obviously far-reaching consequences, they should have folded instead of betting someone else's ranch.

${ }^{129}$ William B. Rubenstein, Divided We Litigate: Addressing Disputes Among Group Members and Lawyers in Civil Rights Campaigns, 106 Yale L J 1623, 1632 (1997). 